\title{
Selection of somaclonal variants of the cultivar 'Prata-Anã' for resistance to Fusarium oxysporum f. sp. cubense race 1
}

\author{
Mileide dos Santos Ferreira ${ }^{1}$, Érica Rodrigues de Moura ${ }^{2}$, Lucymeire Souza Morais Lino ${ }^{3}$, \\ Edson Perito Amorim ${ }^{4}$, Janay Almeida dos Santos-Serejo ${ }^{5}$, Fernando Haddad ${ }^{6}$
}

\begin{abstract}
The banana tree is one of the most cultivated fruit globally; however, some diseases significantly affect its production, such as Fusarium wilt. The most appropriate measure for controlling this disease in areas with inoculum pressure is the use of resistant cultivars. Therefore, this study aimed to generate banana somaclones of the cultivar 'Prata-Anã' resistant to Fusarium wilt by inducing somaclonal variation. 'Prata-Anã' stem apexes were established in vitro in MS culture medium and, on a monthly basis, subcultivated in AIA and adenine sulfate supplemented MS medium with added plant regulators: 6-benzylaminopurine (BAP, $4 \mathrm{ml} \mathrm{L}^{-1}$ ), Thidiazuron (TDZ, $1 \mathrm{ml} \mathrm{L}^{-1}$ ), and Paclobutrazol (PBZ, $10 \mathrm{ml} \mathrm{L}^{-1}$ ). The treatments were: T0: no regulator, T1: BAP, T2: TDZ, T3: PBZ, T4: BAP + TDZ, T5: BAP + PBZ, T6: TDZ + PBZ, and T7: BAP + TDZ + PBZ. After the twelfth subculture, the regenerated plants were planted in boxes containing sterile soil infected with Fusarium oxysporum f. sp. cubense, and evaluated after 90 days for resistance to the pathogen. Somaclonal variants T2-1 and T2-2, generated in Treatment 2, with TDZ, were selected as resistant. This result is promising for the launch of a new Fusarium race 1-resistant banana variety. Index terms: Biotechnology; Tissue culture; Musa sp.; Somaclonal variations; Fusarium wilt.
\end{abstract}

\section{Seleção de variantes somaclonais da cultivar 'Prata-Anã' para resistência à Fusarium oxysporum f. sp. cubense raça 1}

Corresponding author: mileideferreira12@gmail.com

Received: March 13, 2020 Accepted: August 20, 2020

Copyright: All the contents of this journal, except where otherwise noted, is licensed under a Creative Commons Attribution License.

\section{(cc) EY}

Resumo -A bananeira é uma das frutíferas mais cultivadas no mundo; entretanto, algumas doenças têm afetado sua produção, como a murcha de Fusarium. Em áreas onde há pressão de inóculo, a medida mais adequada no controle da doença é a utilização de cultivares resistentes. Diante disso, o objetivo deste trabalho foi obter somaclones de bananeira da cultivar 'Prata-Anã' resistentes à murcha de Fusarium pela indução de variação somaclonal. Para isso, ápices caulinares de bananeira 'Prata-Anã' foram estabelecidos in vitro, em meio de cultura MS. Em seguida, foram transferidos e subcultivados mensalmente para meio MS, suplementado com AIA e sulfato de adenina, acrescidos de diferentes combinações de reguladores: 6-benzilaminopurina BAP $\left(4 \mathrm{ml} . \mathrm{L}^{-1}\right)$, Thidiazuron TDZ (1 ml. $\left.\mathrm{L}^{-1}\right)$ e Paclobutrazol PBZ (10 ml. $\left.\mathrm{L}^{-1}\right)$. Os tratamentos foram: T0: sem regulador; T1: BAP; T2: TDZ; T3: PBZ; T4: BAP + TDZ; T5: BAP + PBZ; T6: TDZ + PBZ; 7: BAP + TDZ + PBZ. As plantas regeneradas, após o décimo segundo subcultivo, foram posteriormente plantadas em caixas d'água contendo solo estéril e infestado com $F o c$, e aos 90 dias foram avaliadas quanto à resistência ao patógeno. Foram selecionados os variantes somaclonais T2-1 e T2-2, resultantes do tratamento 2 com TDZ, como resistentes. Esse resultado é promissor para o lançamento de uma nova variedade de bananeira resistente à murcha de Fusarium raça 1 .

Termos para indexação: Biotecnologia; Cultura de tecidos; Musa sp; Variações somaclonais; Murcha de Fusarium.

\footnotetext{
${ }^{1}$ Biologist, Master Student in Agricultural Microbiology, Universidade Federal do Recôncavo da Bahia, Cruz das Almas - BA, Brasil. E-mail: mileideferreira12@gmail.com ${ }^{\text {(ORCID: 0000-0003-3424-2799) }}$

${ }^{2}$ Biology Student, Universidade Federal do Recôncavo da Bahia, Cruz das Almas - BA, Brasil. E-mail: rodrigues07erica@gmail.com ${ }^{\text {(ORCID: }}$ 0000-0002-5295-2156)

${ }^{3}$ Agronomist, PhD., Post doctoral at Embrapa Mandioca e Fruticultura, Cruz das Almas - BA, Brasil. E-mail: lucymeire.lino@gmail.com (ORCID: 0000-0001-6400-8034)

${ }^{4}$ Agronomist, PhD., Researcher at Embrapa Mandioca e Fruticultura, Cruz das Almas - BA, Brasil. E-mail: edson.amorim@embrapa.br ${ }^{\text {(ORCID: }}$ 0000-0001-9086-7385)

${ }^{5}$ Agronomist, PhD., Researcher at Embrapa Mandioca e Fruticultura, Cruz das Almas - BA, Brasil. E-mail: janay.almeida@embrapa.br (ORCID: 0000-0003-3793-1792

${ }^{6}$ Agronomist, PhD., Researcher at Embrapa Mandioca e Fruticultura, Cruz das Almas - BA, Brasil. E-mail: fernando.haddad@embrapa.br (ORCID: 0000-0003-0332-3270)
} 


\section{Introduction}

Bananas are a source of nutrients and income for thousands of families in several countries around the world, such as India, China, Indonesia, Brazil, and some countries of Africa. Brazil is the fourth largest banana producer, accounting for approximately seven million tons of fruit (FAOSTAT, 2018). Prata subgroup cultivars, such as 'Prata-Anã', and derivative selections such as 'Gorutuba' and 'Catarina', form the basis of Brazilian production, representing approximately $70 \%$ of the area in the country cultivated with this fruit (IBGE, 2016; COLTRO; KARASKI, 2019). Banana production in Brazil is characterized by small producers and a domestic consumption of 65 to $70 \%$ of total production, demonstrating its social importance in terms of food security, job creation, and subsistence (COLTRO; KARASKI, 2019).

Both the production of bananas for subsistence, and for the local and export fruit trade are threatened by the occurrence of Fusarium wilt, caused by the fungus Fusarium oxysporum f. sp. cubense (Foc) (PLOETZ, 2015; DITA et al., 2018). In addition to concerns about managing the pandemic caused by tropical race 4 (TR4) of the pathogen, some countries are searching for strategies to cope with race 1 which is endemic in the main banana producing regions of the world (ARINAITWE et al., 2019; GONÇALVEZ et al., 2019). In Brazil, there are no records of TR4; however, Foc race 1 has had a great impact, either by reducing the productivity of banana plantations or by making the soil unsuitable for planting susceptible cultivars, especially in fields under irrigation which constitute a large proportion of banana production areas (REBOUÇAS et al., 2018; GONÇALVEZ et al., 2019).

The fungus $F O C$ is a soil-dwelling pathogen that penetrates the roots of the banana tree and colonizes the tissue, affecting xylem vessels and leading to symptoms such as progressive leaf yellowing, pseudostem cracks, leaf wilt, and plant death (DITA et al., 2018). In addition, the pathogen produces resistant structures called chlamydospores which enable it to survive in the soil for many years (PLOETZ, 2015). Cultural and biological disease control practices are not efficient for controlling Foc, especially with high inoculum pressure in very susceptible cultivars, but have shown promising results when associated with less susceptible cultivars with quantitative resistance (HADDAD et al., 2018). So far, the results clearly indicate that the most viable disease management strategy is the development of resistant cultivars (REBOUÇAS et al., 2018; ARINAITWE et al., 2019; GONÇALVEZ et al., 2019). However, most cultivars of the genus Musa have high levels of sterility and low seed production, which makes conventional breeding a significant challenge, despite the development of hybrids resistant to Foc race 1 by some breeding programs, such as the Honduran Agricultural Research Foundation (FHIA), and the Brazilian Agricultural Research Corporation (Embrapa) (AMORIM et al., 2011; KHAYAT et al., 2011).

The exploration of somaclonal variations that occur during the micropropagation process is an alternative strategy to progeny breeding and selection programs (CHEN et al., 2013; GHAG et al., 2014). This approach is related to the occurrence of genetic changes induced by in vitro cultivation, which can cause genetic or epigenetic variation (PENNA et al., 2019; ANIL et al., 2018). A clear demonstration of success with somaclonal variants resistant to TR4 occurred in Taiwan using the cultivar 'Giant Cavendish' (HWANG; KO, 2004). Another study, using somatic embryos kept in tissue culture for an extended period to generate somaclones which were then challenged with Foc race 1, found that four of the 26 banana cv. 'Rasthali' somaclones presented greater Foc resistance. In addition, cDNA-RAPD analysis identified at least one differentially expressed gene (lipoxygenase) in these somaclones (GHAG et al., 2014).

In the present study, 'Prata-Anã' stem apexes were subcultured in culture medium with different growth regulator combinations and successive cultivations to generate and select somaclonal variants resistant to Foc race 1 .

\section{Material and methods}

\section{Plant material, tissue culture and plant regeneration}

Banana plants derived from cv. 'Prata-Anã' (Musa spp. AAB) were obtained from the Embrapa Mandioca e Fruticultura. The stem apexes were disinfected and established in vitro in a culture medium containing MS (Murashige \& Skoog, 1962) salts and vitamins, and cultured for 15 days in the dark and 15 days in a growth room under a 16-hour photoperiod and photon flux density of $30 \mu \mathrm{E} \mathrm{m}^{-2} \mathrm{~s}^{-1}$ at $27 \pm 2{ }^{\circ} \mathrm{C}$. Thereafter, on a monthly basis, they were transferred and subcultured in MS medium supplemented with AIA and adenine sulfate to which was added different combinations of the plant regulators: 6-benzylaminopurine (BAP, $4 \mathrm{ml} . \mathrm{L}-1$ ), Thidiazuron (TDZ, $1 \mathrm{ml} \mathrm{L}^{-1}$ ), and Paclobutrazol (PBZ, $10 \mathrm{ml} \mathrm{L}^{-1}$ ), as follows: Treatment 1 (T1) BAP, Treatment 2 (T2) TDZ, Treatment 3 (T3) PBZ, Treatment 4 (T4) BAP + TDZ, Treatment 5 (T5) BAP + PBZ, Treatment 6 (T6) TDZ + PBZ, and Treatment 7 (T7) BAP + TDZ + PBZ (Table 1). 
Table 1. Plant regulators used in the micropropagation process to generate 'Prata-Anã' somaclonal variants resistant to Fusarium wilt race 1.

\begin{tabular}{|c|c|}
\hline Sign & Treatments \\
\hline T0 & Without regulator \\
\hline $\mathrm{T} 1$ & 6-benzilaminopurina BAP $\left(4 \mathrm{ml} . \mathrm{L}^{-1}\right)$ \\
\hline $\mathrm{T} 2$ & Thidiazuron TDZ (1 ml.L $\left.\mathrm{L}^{-1}\right)$ \\
\hline $\mathrm{T} 3$ & Paclobutrazol PBZ (10 ml. L-1) \\
\hline $\mathrm{T} 4$ & 6-benzilaminopurina BAP $\left(4 \mathrm{ml} . \mathrm{L}^{-1}\right)+$ Thidiazuron TDZ $\left(1 \mathrm{ml} . \mathrm{L}^{-1}\right)$ \\
\hline T5 & 6-benzilaminopurina BAP $\left(4 \mathrm{ml} . \mathrm{L}^{-1}\right)+$ Paclobutrazol PBZ $\left(10 \mathrm{ml} . \mathrm{L}^{-1}\right)$ \\
\hline T6 & Thidiazuron TDZ $\left(1 \mathrm{ml} \cdot \mathrm{L}^{-1}\right)+$ Paclobutrazol PBZ $\left(10 \mathrm{ml} \cdot \mathrm{L}^{-1}\right)$ \\
\hline $\mathrm{T} 7$ & 6-benzilaminopurina BAP $\left(4 \mathrm{ml} . \mathrm{L}^{-1}\right)+$ Thidiazuron TDZ $\left(1 \mathrm{ml} \cdot \mathrm{L}^{-1}\right)+$ Paclobutrazol PBZ $\left(10 \mathrm{ml} \cdot \mathrm{L}^{-1}\right)$ \\
\hline
\end{tabular}

A total of 12 subcultures were conducted at 30 - to 40-day intervals. At the end of the subculture process, the sprouts were individualized and converted into plants, then transferred to MS medium without regulator for rooting. After 30 days, the rooted plants were transferred to tubes containing substrate and acclimated in a greenhouse for 30 to 45 days, until they reached a height of approximately $15 \mathrm{~cm}$

\section{Fungus culture and inoculum preparation}

This study used the CNPMF 218A isolate from $F O c$ race 1, obtained from the biological collection of $F$. oxysporum f. sp. cubense from the Embrapa Laboratory of Phytopathology. This isolate was selected for its virulence and aggressive infection of banana cultivars (HADDAD et al., 2011; COSTA et al., 2015; ROCHA et al., 2020).

The Foc 1 isolate was grown on potato dextrose agar at $25^{\circ} \mathrm{C}$ under a 12 -hour photoperiod. After colony growth, a suspension of conidia was prepared and approximately $20 \mathrm{~mL}$ of this deposited in $1 \mathrm{~kg}$ of sterilized rice. Subsequently, the culture medium was incubated at $25{ }^{\circ} \mathrm{C}$ under a 12 -hour photoperiod. After 20 days, colony-forming units (CFU) were counted using a serial dilution to verify the spore concentration and viability. The CFU were counted using a Neubauer camera. The concentration used for inoculations was $10^{6} \mathrm{CFU} \mathrm{g}^{-1}$ of substrate (MADIGAN et al., 2016).

\section{Preliminary selection of Fusarium wilt resistant somaclones}

The experiment was conducted in a greenhouse using $310 \mathrm{~L}$ polyethylene boxes filled with autoclaved soil which was subsequently infected with $1 \mathrm{~kg}$ of the $F o c$ inoculum. 'Prata-Anã' banana plants, approximately 15 $\mathrm{cm}$ high, were planted in the Foc infected soil at a density of 30 seedlings per box. Non-treated 'Prata-Anã' seedlings were planted in each box as a positive control. A total of 2,520 plants subjected to seven treatments (Table 1) were planted, with 360 plants evaluated per treatment.

After 90 days or plant death, internal symptoms of rhizome discoloration were evaluated using the grading scale (ranging from 1 to 5) proposed by Dita et al. (2014), where 1: absence of symptoms, 2: rhizome with initial discoloration, 3: rhizome discoloration throughout the vascular system, 4: rhizome with most internal tissues presenting necrosis, and 5: fully necrotic rhizome.

Plants with no symptoms of disease or with the lowest disease severity score were designated as putative Fusarium wilt race 1 resistant somaclones. These seedlings were used as the source material for further tissue culture, where they were introduced in vitro and micro-propagated for a second experiment to verify their Foc resistance.

Confirmation of resistance in selected somaclones

The micro-propagated seedlings of the somaclones supposedly resistant to Fusarium wilt (identified in the preliminary selection) were replanted in the infected soil, in a completely randomized design with ten replicates for each somaclone.

In this second experiment, the plants were evaluated for external leaf yellowing symptoms using the grading scale of Dita et al. (2014), where 1: no symptoms, 2: initial yellowing in old leaves, 3 : yellowing in old leaves and initial discoloration in new leaves, 4 : intense yellowing in all leaves, and 5: plant death. The symptoms were recorded from onset up to 60 days, at seven-day intervals. External leaf symptom indexes were determined from the scores and used to calculate the area under the disease progress curve (AUDPC) using the formula proposed by Shaner and Finney (1977). 
Internal symptoms were analyzed using transverse rhizome sections of the plants 60 days after inoculation or after plant death, applying the same internal symptom grading scale as used in the preliminary experiment (DITA et al., 2014). The scores obtained were used to calculate internal indexes ID (\%) values of Fusarium wilt symptoms.

Evaluation of fungal structures in the root tissue of the somaclones tested for Fusarium wilt resistance

Histological evaluation was performed for the putative somaclones identified in the preliminary test and for those used in the resistance confirmation experiment. In both cases, root fragments were collected after the final internal symptom evaluation during which the rhizomes were sectioned. The Phillips and Haymann (1970) protocol was used for root staining. The root fragments were soaked for $1 \mathrm{~h}$ in a $10 \%$ potassium hydroxide $(\mathrm{KOH})$ solution in a water bath at $90{ }^{\circ} \mathrm{C}$. Thereafter, the solution was discarded and the biological material washed in water to remove all the $\mathrm{KOH}$. The roots were then transferred to a $1 \% \mathrm{HCl}$ solution for a $5 \mathrm{~min}$ period. The $\mathrm{HCl}$ solution was discarded and the roots were stained using Trypan Blue in a $0.05 \%$ lactoglycerol solution $(2: 1: 1$, lactic acid: glycerin: water) and boiled in a microwave for $40 \mathrm{sec}$ after which the dye was discarded. The roots were then immersed in lactoglycerol solution (2:1:1; lactic acid: glycerin: water) to remove excess dye. The root fragments were visualized and microphotographed under a light microscope.

\section{Statistical analysis}

Regarding the preliminary test internal symptom evaluation scores, the frequency of each score per plant was calculated and converted to a percentage. To study the treatments, a cluster analysis using color was also performed, based on a heat map prepared by transforming the internal symptom scores into a binary matrix, where 0 was assigned to plants without symptoms and 1 to plants with disease symptoms. The data for each plant was represented by a color, where green was associated with resistance and red with susceptibility. The ID symptoms and AUDPC data obtained from the second experiment were subjected to analysis of variance, and the means were grouped by the Scott-Knott test at 5\% significance. The analyses were performed using the R software.

\section{Results and discussion}

A total of 360 'Prata-Anã' banana seedlings without treatment (susceptible control) and 2,520 somaclonal variants from 12 subcultures with different plant regulator combinations were analyzed for $F o c$ race 1 resistance in the preliminary test. Most control plants died within 60 days of planting in Foc-infected soil, and only $0.079 \%$ of the treatment plants were symptomless, which amounted to 20 plants out of the 2,520 somaclonal variants. The percentage of plants in each treatment $(n=360)$ with a score of 1 on the internal symptom scale was $2.7 \%$ in $\mathrm{T} 2$ (TDZ), $0.5 \%$ in T4 (BAP + TDZ), $0.8 \%$ in T5 (BAP + PBZ), and $1.3 \%$ in T6 (TDZ + PBZ) (Figure 1).

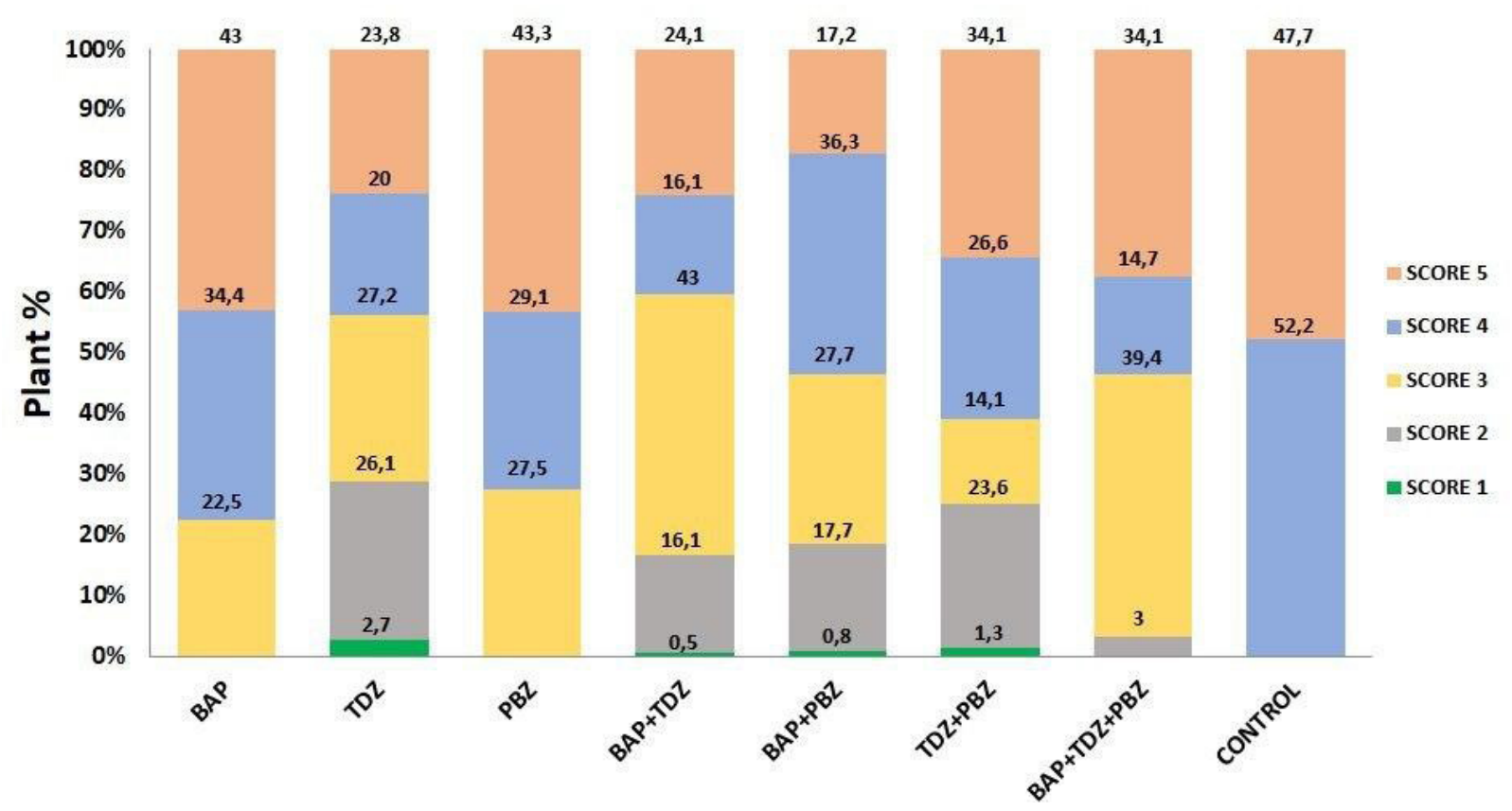

Figure 1. Percentage of plants per grade according to the rhizome internal symptoms scale proposed by Dita et al. (2014) for 'Prata-Anã' banana somaclones induced with plant regulators to generate variants resistant to Fusarium wilt. A total of 2,520 plants (360 per treatment) and 360 control plants were used. Control: 'Prata-Anã' cultivar. Treatments: BAP (6-benzylaminopurine), TDZ (Thidiazuron), PBZ (Paclobutrazol), BAP + TDZ, BAP + PBZ, TDZ + PBZ, BAP + TDZ + PBZ. Internal symptoms scale: $1=$ absence of symptoms, 2 = rhizome with initial discoloration, $3=$ rhizome discoloration throughout the vascular system, $4=$ rhizome with most internal tissues presenting necrosis, and $5=$ fully necrotic rhizome. 
Owing to contamination problems and losses during the in vitro micro-propagation process for the second experiment, only four plants were regenerated and used in the next stage. These plants were designated as putative Fusarium wilt race 1 resistant somaclones and named T2-1, T2-2, T4-1, and T5-1. Contamination during the micropropagation process may be related to Foc structures in the tissues of plants which, although not manifesting symptoms, may have been infected. Some resistance mechanisms are known to form after infection such that the pathogen enters the tissues, but cannot establish itself because the plant resistance response is faster (LI et al., 2015). The presence of toxins released by the fungus in rhizome tissues is also likely, since $F o c$ is a necrotrophic fungus that releases toxins to destroy host tissues (PLOETZ, 2015). Some of the main phytotoxins produced by $F O C$ are fusaric acid and beauvericin (PORTAL et al., 2018).

A low number of somaclones without symptoms was generated in this study. This result was expected as genetic variation induction is known to occur in low percentages. A similar study in Taiwan induced somaclonal variation in 20,000 Cavendish banana seedlings planted in a field infected with Foc TR 4 and reported approximately $0.01 \%$ of genotypes resistant to Fusarium wilt. This particular study registered GCTCV-218, a somaclonal variant of Cavendish resistant to Fusarium wilt, for commercial cultivation under the name Formosona, and two other Cavendish somaclonal variants named GCTCV-53 and GCTCV-119 were identified (HWANG; KO, 2004). The findings of the present study indicate that the use of plant regulators in association with successive in vitro multiplication may lead to greater efficiency in generating resistant somaclonal variants because the study conducted in Taiwan showed a lower percentage of resistant variants $(0.01 \%)$ than were found in the present study $(0.079 \%)$.

A study by Ghag et al. (2014) regenerated four genotypes of cv. 'Rasthali' banana plants resistant to Fusarium wilt using the somaclonal variation tool. In this study, embryos were repeatedly subcultured and maintained for 14 years under tissue culture conditions. This indicates a low frequency of mutations acting on resistance, requiring a significant number of plants or a long period of subcultures to increase the chances of selecting possible somaclonal variants that are resistant to the disease.

Figure 2 shows the incidence of plants with symptoms (highlighted in red) and plants not showing symptoms (highlighted in green) and indicates that a small amount of genetic variability occurred for the resistance factor in the 2,520 somaclonal variants evaluated, considering that most of them showed Foc susceptibility (Figure 2). The treatment with the highest number of plants without symptoms was T2 (TDZ), represented by the T2-1 and T2-2 somaclones. This finding indicates that TDZ used on its own and not combined with other plant regulators in the culture medium was most effective in the generation of somaclonal variants resistant to Foc race 1. Thidiazuron is a plant regulator of the cytokinin group, responsible for cell division and used in many studies to induce organogenesis and embryogenesis (PELAH et al., 2002; SHEIBANI et al., 2006; AHMAD et al., 2018).

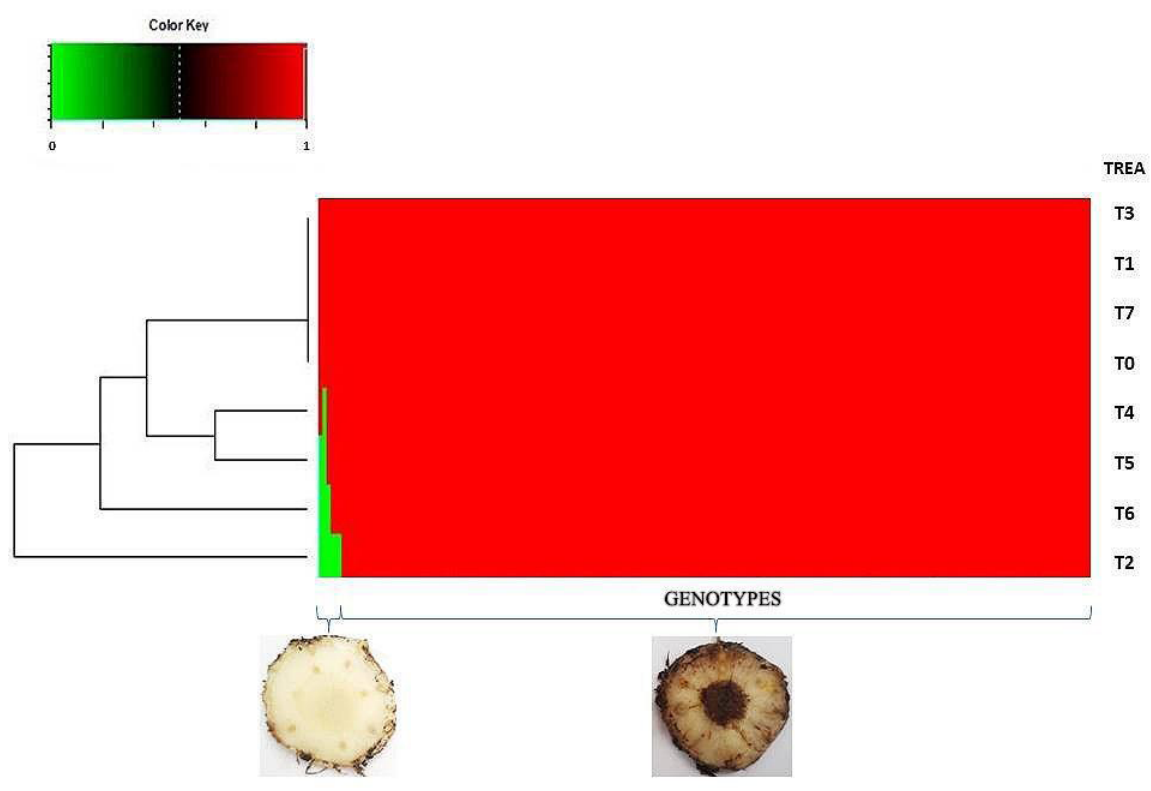

Figure 2. Heat map of the presence (red) and absence (green) of Fusarium wilt symptoms in 'Prata-Anã' banana somaclonal variants evaluated in a greenhouse after Fusarium oxysporum f. sp. cubense race 1 resistance induction with plant regulators. The tree on the left shows the hierarchical grouping of treatments. T0: control ('Prata-Anã'), T1: 6-benzylaminopurine, T2: Thidiazuron, T3: Paclobutrazol, T4: 6-benzylaminopurine + Thidiazuron, T5: 6-benzylaminopurine + Paclobutrazol, T6: Thidiazuron + Paclobutrazol, T7: 6-benzylaminopurine + Thidiazuron + Paclobutrazol, TRAT: treatments. 
A study by Goelzer et al. (2019) showed that a combination of TDZ and ANA had a negative effect on sprout growth, suggesting that the use of TDZ alone in the culture medium intensified cytokinin effects on cell division, which could cause DNA polymerase errors, consequently generating mutations. This may account for why, in this study, T2 (TDZ) emerged as the best treatment for generating possible genetic variation in comparison with the other treatments that used combinations of plant regulators.

Analysis of the second experiment results confirmed the resistance of the somaclonal variants T2-1 and T2-2. Evaluation of the external symptoms of somaclones T2-1 and T2-2 by AUDPC yielded a value of 250. This was statistically different from the AUDPC values of somaclones T4-1, T5-1, and T0 (control), which had AUDPC values ranging from 600 to 1,500 (Figure $3)$. As for the internal symptoms evaluated by the ID, the somaclonal variants T2-1 and T2-2 had the lowest

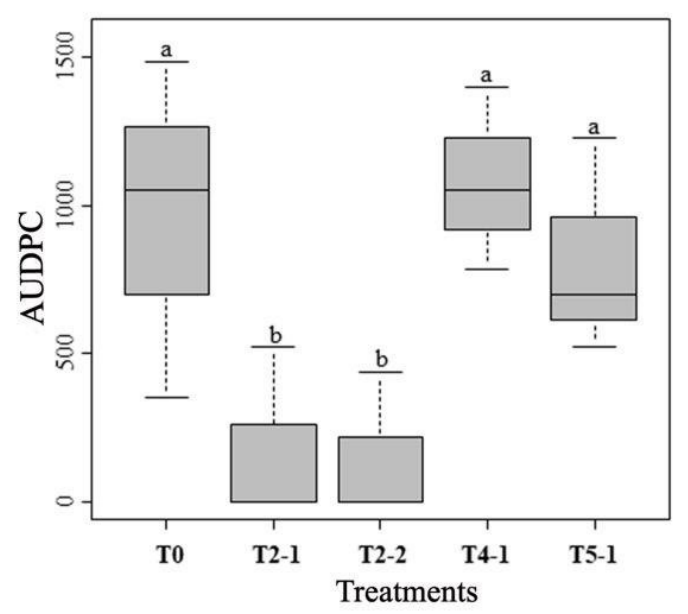

indexes ( $0 \%$ and $5 \%$, respectively). These values were statistically different to the ID values of somaclones T41, T5-1, and T0, which ranged from 40 to $70 \%$ (Figure 3). The transverse sections of plant rhizomes showed characteristic Fusarium wilt symptoms, with reddish brown coloration in the vascular tissues in T4-1, T5-1, and T0 (Figure 3 A, D, E). Through these analyses, somaclones T4-1 and T5-1, which appeared to be Foc resistant during the preliminary test, were shown to be susceptible to Fusarium wilt during the second experiment.

The histological evaluation at the end of the preliminary test revealed $F O C$ structures such as chlamydospores and hyphae in the tissues of T0 and somaclonal variant T2-2 only (Figure $4 \mathrm{~A}$ and $\mathrm{C}$ ). At the end of the second experiment to confirm resistance, the histological evaluation showed that somaclonal variants T2-2, T4-1, T5-1 and T0 had Foc structures inside the root tissues. However, the T2-1 variant lacked evidence of fungal structures in the tissues, corroborating the preliminary test result for this somaclone (Figure $4 \mathrm{~B}$ and $G)$.
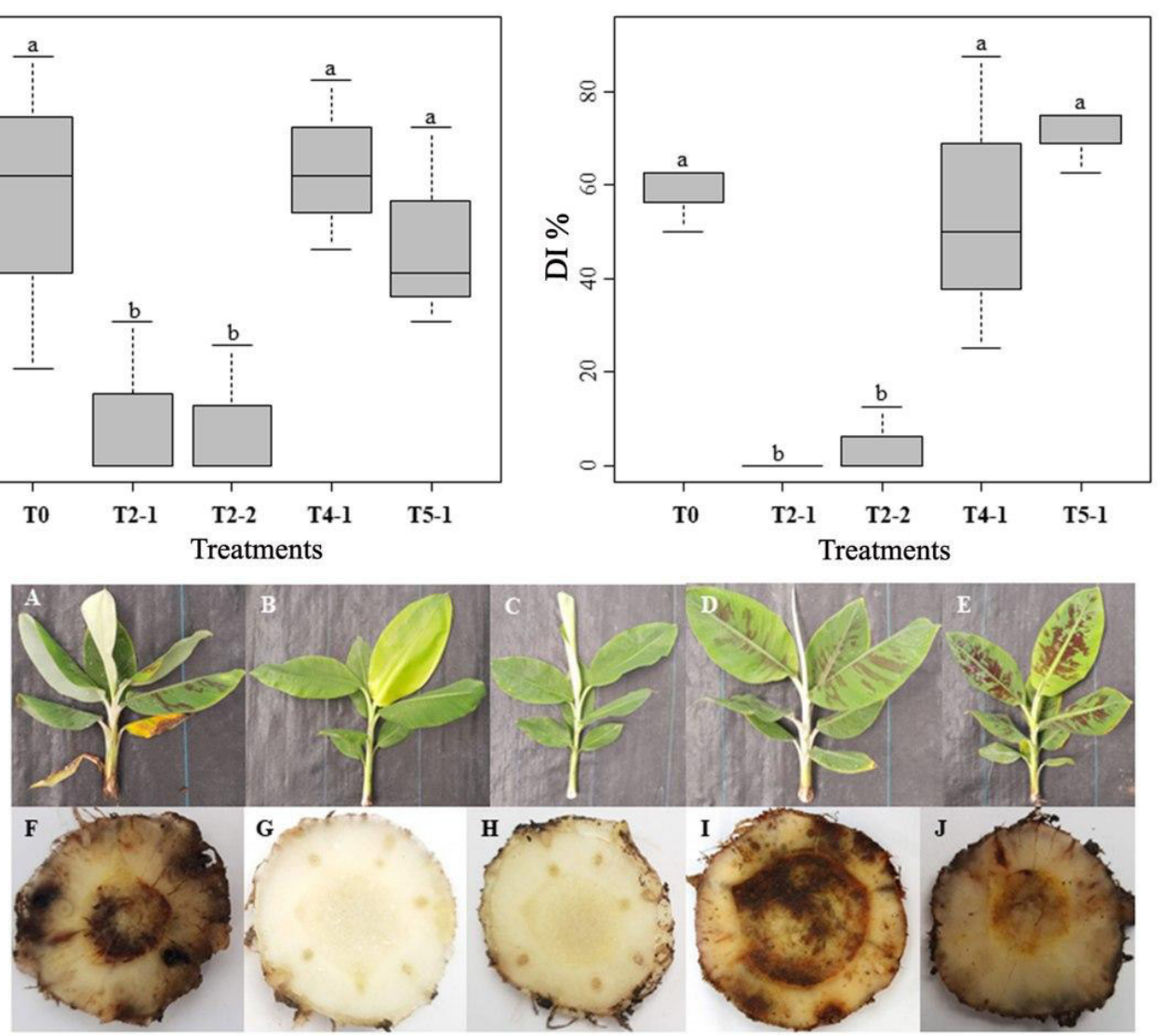

Figure 3. Boxplots of the area under the disease progress curve (AUDPC) and the disease index (ID) of 'Prata-Anã' banana plants evaluated in a greenhouse after somaclonal variation induction with plant regulators for Fusarium wilt resistance. T0: 'Prata-Anã' control without induction, T2-1: variant induced with Thidiazuron, T2-2: variant induced with Thidiazuron, T4-1: variant induced with 6-benzylaminopurine + Thidiazuron, T5-1: variant induced with 6-benzylaminopurine + Paclobutrazol. The bars followed by the same letter do not differ by the Scott-Knott test $(p<$ 0.05). Typical external leaf yellowing symptoms are shown from A to E, and transverse sections of the rhizome showing internal symptoms from $\mathrm{F}$ to $\mathrm{J}$. The plants were evaluated for symptoms 90 days after inoculation with Fusarium oxysporum f. sp. cubense race 1 in a greenhouse. 'Prata-Anã' (susceptible control) (A, F), T2R1 variant induced with Thidiazuron $(B, G), T 2 R 2$ variant induced with Thidiazuron $(C, H)$, T4R1 variant induced with 6-benzylaminopurine + Thidiazuron (D, I), T5R1 variant induced with 6-benzylaminopurine + Paclobutrazol (E, J). 


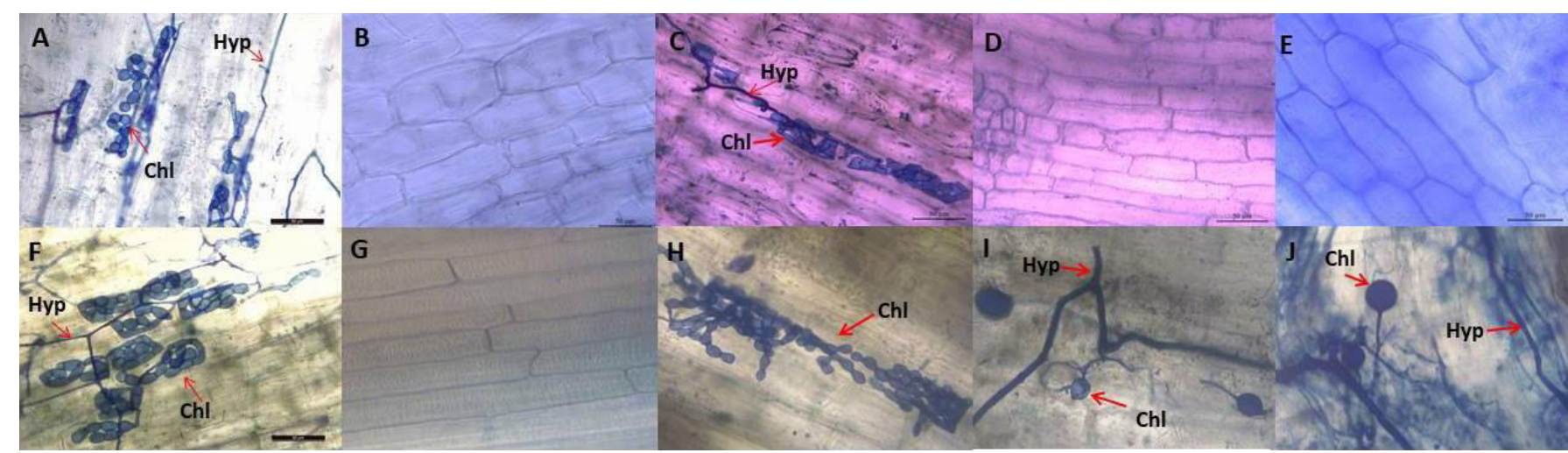

Figure 4. Histological evaluation of internal root tissues of 'Prata-Anã' banana plants induced by somaclonal variation with plant regulators for Fusarium wilt resistance caused by Fusarium oxysporum f. sp. cubense (Foc). First stage of the study (A, B, C, D, E): Only the 'Prata-Anã' control (A) and the T2-2 somaclonal variant (C) had Foc structures. Second stage of the study (F, G, H, I, J): All somaclonal variants had Foc structures, except T2-1 (G). The roots were clarified, and Foc structures were stained with Trypan Blue. 'Prata-Anã' control without induction showing pathogen colonization and sporulation in the tissue (A and F), T2-1 somaclonal variant induced with Thidiazuron (B and G), T2-2 somaclonal variant induced with Thidiazuron $(\mathrm{C}$ and $\mathrm{H})$, T4-1 somaclonal variant induced with 6-benzylaminopurine + Thidiazuron (D and I), T5-1 somaclonal variant induced with 6-benzylaminopurine + Paclobutrazol (E and J). Chl: chlamydospores, and Hyp: hyphae.

Considering that the absence of pathogen structures in root tissues indicates that the pathogen has not successfully penetrated these tissues, the resistant variant T2-1 may have developed physical and chemical barriers to block pathogen penetration (PETIT-HOUDENOT et al., 2017; BANI et al., 2018). As reported in a histological study by Costa (2013), the cultivar 'BRS Platina', a Foc race 1 resistant 'Prata' cultivar (launched by Embrapa in 2011), showed no Foc structures inside the roots, a finding similar to that for somaclonal T2-1. The T2-2 somaclonal variant showed no external or internal Fusarium wilt symptoms, indicating Foc resistance; however, it had pathogen structures in the root tissues. These findings suggest that, whereas this somaclone has no resistance to
Foc tissue penetration, it has resistance mechanisms that prevent pathogen infection, possibly because the genetic resistance of plants corresponds not only to the capacity to prevent, but also to delay disease development (VALE et al., 2001; LI et al., 2015).

The leaves of the somaclonal variants showed morphological differences. Somaclones T4-1 and T5-1 had reddish spots on their leaves, similar to the spots on the T0 leaves (Figure 5). The leaves of somaclones T2-1 and T2-2 had no such reddish spots, suggesting some form of genetic modification in these two variants. Previous studies have reported morphological changes in banana trees in relation to somaclonal variation (ALVARES et al., 2002).
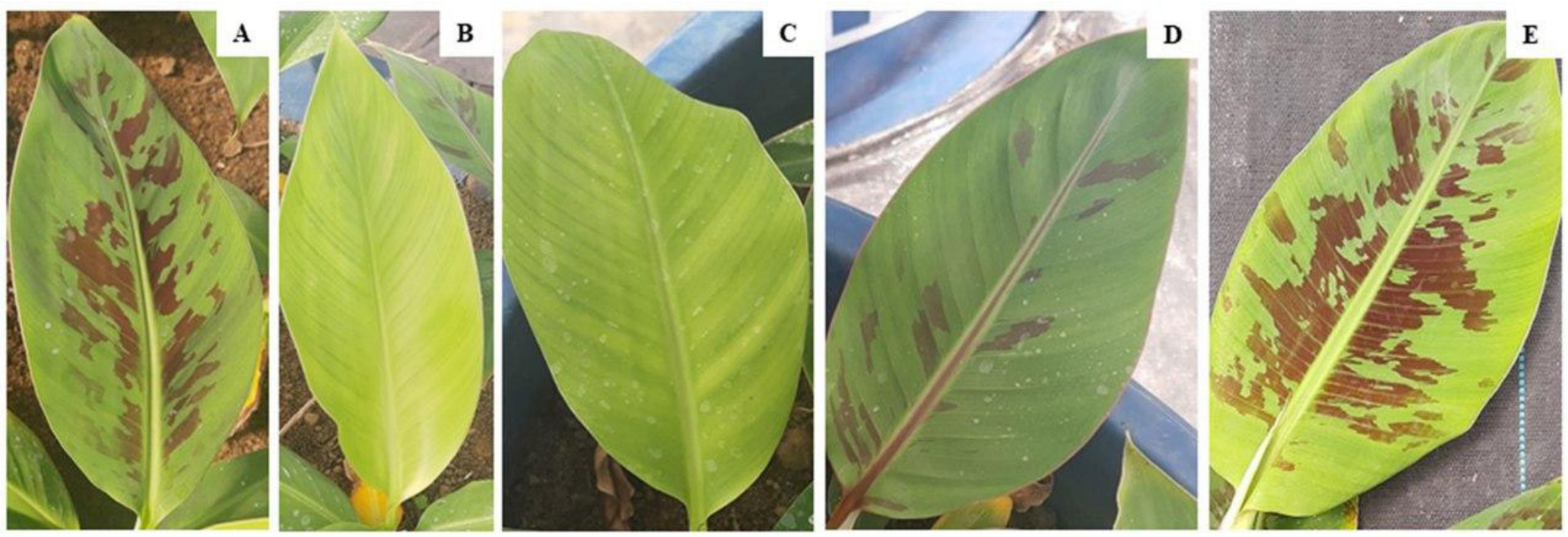

Figure 5. Leaf surface features of 'Prata-Anã' banana plants induced by somaclonal variation with plant regulators for Fusarium wilt resistance. 'Prata-Anã' control without induction showing reddish spots on the leaf surface (A), T2-1 variant induced with Thidiazuron with no leaf surface spots (B), T2-2 variant induced with Thidiazuron with no leaf surface spots (C), T4-1 variant induced with 6-benzylaminopurine + Thidiazuron with reddish spots on the leaf surface similar to the control (D), and T5-1 variant induced with 6-benzylaminopurine + Paclobutrazol with reddish spots on the leaf surface similar to the control (E). 
The pathogen $F o c$ race 1 is present in most banana fields in Brazil. The 'Prata-Anã' cultivar is susceptible to this pathogen and the disease it causes has led to a $60 \%$ loss in production in plantations around the country. This fungus produces chlamydospores, resistant structures that can survive long periods in the soil (PLOETZ, 2015; PEGG et al., 2019). Cultural, chemical, and biological control methods have not been effective in controlling the disease (TUSHE-MEREIRWE et al., 2000; KARANGWA et al., 2016), consequently, identification of a 'Prata-Anã' somaclone resistant to Fusarium wilt race 1 that maintains other agronomic and sensory characteristics of the original cultivar is essential to protect the cultivar and ensure that it continues to be a source of income for farmers, especially given its preference by Brazilian consumers (IBGE, 2016; MOSTERT et al., 2017; HADDAD et al., 2018).

The findings of this study demonstrate that somaclones T2-1 and T2-2 are promising variants for further studies by the Embrapa banana genetic improvement program. Such studies should include both agronomic characterization to confirm the permanence of desirable characteristics similar to those of the 'Prata-Anã' cultivar, and the elucidation of resistance mechanisms generated in these somaclones. The results of current and future research on the somaclones generated in this study will have a significant impact on the launch of a new Fusarium race 1 wilt resistant cultivar.

\section{Conclusion}

Induction of somaclonal variations of the 'PrataAnã' cultivar is viable. as indicated by the generation of the somaclones T2-1 and T2-2, which showed evidence of resistance to Fusarium wilt race 1 .

\section{Acknowledgment}

The authors thank the Coordination for the Improvement of Higher Education Personnel (CAPES) for granting the scholarship, the Breeding Better Bananas/ IITA/Bill and Melinda Gates Foundation project, and Embrapa Cassava and Fruit Crops for providing the facilities for conducting the study.

\section{References}

AHMAD, N.; FAISAL, M.; HUSSAIN, S.A.; ANIS, $M$. Regulation of morphogenesis and improvement in shoot multiplication in vitex species using thidiazuron. In: AHMAD, N.; FAISAL, M. Thidiazuron: from urea derivative to plant growth regulator. Singapor: Springer Nature, 2018. p.343-349.

ALFENAS, A.C.; MAFIA, R.G. (ed.). Métodos em fitopatologia. Viçosa: UFV, 2007. p.382.

ÁLVARES, M.C.; CALDAS, L.S. Crescimento, produção e variação somaclonal em bananeiras micropropagadas. Pesquisa Agropecuária Brasileira, Brasília, DF, v.37, n.3, p.415-420, 2002.

AMORIM, E.P.; AMORIM, V.B.O.; SILVA, S.O.; PILLAY, M. Quality Improvement of Cultivated Musa. In: PILlAY, M.; TENKOUANO, A. (ed.). Banana breeding: progress and challenges. New York: CRC Press, 2011. p. 251.

ANIL, V.S.; LOBO S.; BENNUR S. Somaclonal variations for crop improvement: selection for disease resistant variants in vitro. Plant Science Today, Thiruvanthapuram, v.5, n. 2, p. 44-54, 2018.

ARINAITWE, I.K.; TEO, C.H.; KAYAT, F.; TUMUHIMBISE, R.; UWIMANA, B.; KUBIRIBA, J.; OTHMAN, R.Y. Evaluation of banana germplasm and genetic analysis of an $\mathrm{F} 1$ population for resistance to Fusarium oxysporum f. sp. cubense race 1. Euphytica, Dordrecht, v.215, n.10, p.175, 2019.

BANI, M.; PÉREZ-DE-LUQUE, A.; RUBIALES, D.; RISPAIL, N. Physical and chemical barriers in root tissues contribute to quantitative resistance to Fusarium oxysporum f. sp. pisi in pea. Frontiers in Plant Science, Lausanne, v.9, p.199, 2018.

BUBICI G.; KAUSHAL M.; PRIGIGALLO MI.; GÓMEZ-LAMA CC.; MERCADO-BLANCO J. Biological control agents against Fusarium wilt of banana. Frontiers in Microbiology, Dordrecht, v.10, p.616, 2019.

CHEN, Y.F.; CHEN, W.; HUANG, X.; HU, X.; ZHAO, J.T.; GONG, Q.; HUANG, X.L. Fusarium wilt resistant lines of Brazil banana (Musa spp.; AAA) obtained by EMS-induced mutation in a microcross section cultural system. Plant Pathology, Oxford, v.62, p.112-119, 2013. 
COLTRO, L; KARASKI, TU. Environmental indicators of banana production in Brazil: Cavendish and Prata varieties. Journal of Cleaner Production, Amsterdam, v.207, p.363-378, 2019.

COSTA, S.N.; BRAGANÇA, C.A.D.; RIBEIRO, L.R.; AMORIM, E.P.; OLIVEIRA, S.A.S.; DITA, M.A.; HADDAD, F. Genetic structure of Fusarium oxysporum f.sp.cubense in different regions from Brazil. Plant Pathology, Oxford, v.64, n.1, p.137-146, 2015.

DITA, M.; BARQUERO, M.; HECK, D.; MIZUBUTI, E.S.; STAVER, C.P. Fusarium wilt of banana: current knowledge on epidemiology and research needs toward sustainable disease management. Frontiers in Plant Science, Lausanne, v.9, p.1468, 2018.

FAOSTAT. Food and Agricultural Organization (FAO). Rome, 2018. Disponível em: http://www.fao. org/faostat/en/\#data/QC. Acesso em: 04 jun. 2020.

GOELZER, A.; DÉO, T.G.; LOPES, G.B.; DAMIANI, C.R.O. Berg (Myrtaceae)/growth regulators in vitro multiplication ofCampomanesia adamantium (Cambess). Brazilian Applied Science Review, Curitiba, v.3, n.2, p.1280-1291, 2019.

GHAG, S.B.; SHEKHAWAT, U.K.; GANAPATHI, T.R. Characterization of Fusarium wilt resistant somaclonal variants of banana cv.Rasthali by cDNARAPD. Molecular Biology Reports, Dordrecht, v.41, n.12, p.7929-7935, 2014.

GONÇALVES, Z.S.; HADDAD, F.; DE OLIVEIRA AMORIM, V.B.; FERREIRA, C.F.; DE OLIVEIRA, S.A.S.; AMORIM, E.P. Agronomic characterization and identification of banana genotypes resistant to Fusarium wilt race 1. European Journal of Plant Pathology, Dordrecht, v.155, n.4, p.1093-1103, 2019.

HADDAD, F.; ROCHA, L.S.; SOARES, A.C.F.; MARTINS, I.P.S.; TEIXEIRA, L.A.J.; STAVER, C.; DITA, M..Management of Fusarium wilt of bananas in Minas Gerais, Brazil. Acta Horticulturae, The Hague, v.1, p.137-146, 2018.

HADDAD, F.; OLIVEIRA, A.S.S.; PERITO, E.A. Coleção biológica de trabalho de Fusarium oxysporum f.sp. cubense do laboratório de fitopatologia. Cruz das Alma: Embrapa Mandioca e Fruticultura, 2011. Disponível em: https://www.infoteca.cnptia.embrapa.br/infoteca/bitstream/doc/920961/1 foldercolecaobiologicadet abalhodefusariumoxysporumINTERNET2.pdf. Acesso em: 20 dec. 2019.
HWANG, S.C.; KO, W.H. Cavendish banana cultivars resistant to Fusarium wilt acquired through somaclonal variation in Taiwan. Plant Disease, New York, v.88, n.6, p.580-588, 2004.

IBGE - Instituto Brasileiro de Geografia e Estatística. Anuário Estatístico do Brasil 2016 Rio de Janeiro, 2016. p.455.

KARANGWA, P.; BLOMME, G.; BEED, F.; NIYONGERE, C.E.; VILJOEN, A. The distribution and incidence of banana Fusarium wilt in subsistence farming systems in east and central Africa. Crop Protection, Farham, v.84, p.132-140, 2016.

KHAYAT, E.; ORTIZ, R. Genetic of important traits in Musa. In: PILLAY, M.; TENKOUANO, A. (org.) Banana breeding: progress and challenges. New York: CRC Press, 2011. p.71-83.

LI, W.; GE, X.; WU, W.; WANG, W.; HU, Y.; MO, Y.; XIE, J. Identification of defense-related genes in banana roots infected by Fusarium oxysporum f. sp. cubense tropical race 4. Euphytica, Dordrecht, v.205, n.3, p.837849, 2015.

MADIGAN, M.T; MARTINKO, J.M; BENDER, K.S; BUCKLEY, D.H; STAHL, D.A. Microbiologia de brock. 14.ed. Porto Alegre: Artmed Editora, 2016.

MCKINNEY, H.H.; MCKINNEY, H.H.; MCKINNEY, H.H.; MCKINNEY, R.V.; MCKINNEY, R.H.; MCKINNEY, R.; SH, H. Influence of soil, temperature and moisture on infection of wheat seedlings by Helminthosporium sativum. Journal of Agricultural Research, Burlington, v.26, p.195-217, 1923.

MOSTERT, D.; MOLINA, A.B.; DANIELLS, J.; FOURIE, G.; HERMANTO, C.; CHAO, C.P.; LI, C. The distribution and host range of the banana Fusarium wilt fungus, Fusarium oxysporum f.sp.cubense, in Asia. PLoS One, v.12, n.7, e.0181630. 2017.

PEGG, K.G.; COATES, L.M.; O’NEILL, W.T.; TURNER, D.W. The epidemiology of Fusarium wilt of banana. Frontiers in Plant Science, Lausanne, v.10, p.1395, 2019.

PELAH, D.; KAUSHIK, R.A.; MIZRAHI, Y.; SITRIT, Y. Organogenesis in the vine cactus Selenicereus megalanthus using thidiazuron. Plant Cell, Tissue and Organ Culture, Dordrecht, v.71, n.1, p.81-84, 2002. 
PENNA, S.; GHAG, S.B.; GANAPATHI, T.R.; JAIN, S.M. Induced genetic diversity in banana. In: NANDWANI, D. (ed.). Genetic diversity in horticultural plants. Cham: Springer, 2019. v.22, p. 273-297.

PÉREZ-VICENTE L.; DITA, M.A.; MARTÍNEZ-DE LA, P.E. Technical manual: Prevention and diagnostic of Fusarium Wilt (Panama disease) of banana caused by Fusarium oxysporum f.sp.cubense Tropical Race 4 (TR4). Roma: FAO, 2014. 75p.

PETIT-HOUDENOT, Y.; FUDAL, I. Complex interactions between fungal avirulence genes and their corresponding plant resistance genes and consequences for disease resistance management. Frontiers in Plant Science, Lausanne, v.8, p.1072, 2017.

PHILLIPS J.M.; HAYMAN D.S. Improved procedures for clearing roots and staining 437 parasitic and vesiculararbuscular mycorrhizal fungi for rapid assessment of infection. Transactions of the British Mycological Society, London, v.55, n.1, p.158-161, 1970.

PLOETZ, R.C. Management of Fusarium wilt of banana: a review with special reference to tropical race 4. Crop Protection, Amesterdam, v.73, p.7-15, 2015.

PORTAL, N.; SOLER, A.; ALPHONSINE, P.A.M.; BORRAS HIDALGO, O.; PORTIELES, R.; PEÑARODRIGUEZ, L.M.; WALTON, J.D. Nonspecific toxins as components of a host specific culture filtrate from Fusarium oxysporum f. sp. cubense race 1. Plant Pathology, Oxford, v.67, n.2, p.467-476, 2018.

REBOUÇAS, T.A.; HADDAD, F.; FERREIRA, C.F.; OLIVEIRA, S.A.S.; LEDO, C.A.S.; AMORIM, E.P. Identification of banana genotypes resistant to Fusarium wilt race 1 underfield and greenhouse conditions. Scientia Horticulturae, New York, v.239, p.308-313, 2018.

ROCHA, A.J.; FERREIRA, M.S.; ROCHA, L.S.; OLIVEIRA, S.A.; AMORIM, E.P.; MIZUBUTI, E.S.; HADDAD, F. Interaction between Fusarium oxysporum f. sp. cubense and Radopholus similis can lead to changes in the resistance of banana cultivars to Fusarium wilt. European Journal of Plant Pathology, Dordrecht, v.4, p.1-15, 2020.
SAHIJRAM, L.; SONEJI, J.R.; BOLLAMMA, K.T. Analyzing somaclonal variation in micropropagated bananas (Musa spp.). In Vitro Cellular Developmental Biology-Plant, Heidelberg, v.39, n.6, p.551-556, 2003.

SANTOS, C.C.; VIEGAS, R.; HERCÍLIO, P. Variação somaclonal em mudas micropropagadas de bananeira, cultivar Pacovan. Bragantia, Campinas, v.63, n.2, p.201-205, 2004.

SHANER, G.; FINNEY, R.E. The effect of nitrogen fertilization on the expression of slow - mildewing resistance in Knox Wheat. Phytopathology, St. Paul, v.67, n.8, p.1051-1056, 1977.

SHEIBANI, M.; NEMATI, S.H.; DAVARINEJAD, G.H.; AZGHANDI, A.V.; HABASHI, A.A. Induction of somatic embryogenesis in saffron using thidiazuron (TDZ). Acta Horticulturae, The Hague, v.739, p. 259$257,2006$.

TUSHEMEREIRWE, W.; KANGIRE, A.; KUBIRIBA, J.; NOWAKUNDA, K. Fusarium wilt resistant banana considered appro-priate replacements for cultivars susceptible to the disease in Uganda. Uganda Journal of Agricultural Science, Entebbe, v.5, p.62-64, 2000.

VALE, F.X.R.; PARLEVLIET, J.E.; ZAMBOLIM, L. Concepts in plant disease resistance. Fitopatologia Brasileira, Brasília, DF, v.26, n.3, p.577-589, 2001.

VELAME, K.V.C. Genes de bananeira candidatos à resistência a murcha de Fusarium raça 1 e caracterização da agressividade e virulência de isolados do fungo. 2017. Tese (Doutorado em Biotecnologia) - Universidade Estadual de Feira de Santana, Feira de Santana, 2017.

ZHENG, S.J.; GARCÍA-BASTIDAS, F.A.; LI, X.D.; ZENG, L.; BAI, T.T.; XU, S.T.; YIN, K.S.; LI, H.X.X.; FU, G.; YU, Y.C.; YANG, L.; NGUYEN, H.C.; DOUANGBOUPHA, B.; KHAING, A.A.; DRENTH, A.; SEIDL, M.F.; MEIJER, H.G.J.; KEMA, G.H.J. New incursions of Fusarium oxysporum f.sp.cubense tropical Race 4 across the Greater Mekong Subregion. Frontiers in Plant Science, Lausanne, v.9, p.457, 2018. 